\title{
ASSESSMENT OF EFFICACY OF TOPICAL PHENYTOIN SODIUM DRESSING AS COMPARED TO CONVENTIONAL MOIST DRESSING IN THE MANAGEMENT OF LEG ULCERS
}

\author{
Srikanth Reddy Challapalli ${ }^{1}$, Munikrishna Salavakam² ${ }^{2}$ Srihari Rao Bathalapalli ${ }^{3}$, Sujana Thalamati ${ }^{4}$
}

\section{HOW TO CITE THIS ARTICLE:}

Srikanth Reddy Challapalli, Munikrishna Salavakam, Srihari Rao Bathalapalli, Sujana Thalamati. "Assessment of Efficacy of Topical Phenytoin Sodium Dressing as Compared to Conventional Moist Dressing in the Management of Leg Ulcers". Journal of Evolution of Medical and Dental Sciences 2015; Vol. 4, Issue 83,

October 15; Page: 14480-14485, DOI: 10.14260/jemds/2015/2060

\begin{abstract}
Chronic leg ulcers are one of the most common surgical conditions in surgical practice. From times immemorial, many methods have been tried to treat these types of ulcers. Many techniques have been tried over the centuries to aid in healing of chronic leg ulcers, but there exists no ideal dressing till date.(1) Phenytoin Sodium, a chemical used in management of Epilepsy, is known to produce gingival Hyperplasia, an indirect evidence to enhanced Fibroblastic activity. The present study was conducted to assess the efficacy of topical Phenytoin solution dressing as compared to conventional moist dressing in the healing process of chronic leg ulcers. Phenytoin Sodium being a cheap drug, is likely to cut down, the cost burden on the individual and the Society, if proven effective. KEYWORDS: Phenytoin Sodium, Topical, Dressing, Management, Leg Ulcers.
\end{abstract}

INTRODUCTION: A chronic ulcer is an ulcer that does not heal in an orderly set of stages and in a predictable amount of time. Ulcers that do not heal within 3 months are often considered chronic. ${ }^{1}$ Chronic leg ulcers are one of the most common surgical conditions in surgical practice. From times immemorial, many methods have been tried to treat these types of ulcers. Many techniques have been tried over the centuries to aid in healing of chronic leg ulcers, but there exists no ideal dressing till date.(1) A frequently observed and unwanted side effect of Phenytoin is gingival hyperplasia.(2) especially in children. This side effect clearly suggests, that Phenytoin can induce the growth of connective tissue, and has the ability to promote wound healing.(3) The effectiveness of topical Phenytoin has been assessed by several clinical trials for different types of wounds.

AIMS AND OBJECTIVES: To compare the efficacy of Topical Phenytoin solution dressing in the test group with conventional moist Saline dressings in the control group, in the healing of chronic Leg ulcers, by comparing.

- Rate of granulation tissue formation.

- Skin graft take up.

- Number of days of hospitalization.

\section{Postulated Mechanisms of Action of Phenytoin:}

1. Stimulation of Fibroblast Proliferation.(1)

2. Enhancing the formation of Granulation Tissue.

3. Decreasing collagenase activity directly or by Inhibition of Glucocorticoid Activity.(4)

4. Direct or Indirect Antibacterial activity, by affecting inflammatory cells. ${ }^{(4)}$

5. Phenytoin increases Gene Expression of the Platelet Derived Growth Factor.(4) 


\section{ORIGINAL ARTICLE}

Bansal and Mukul.(1) compared the wound healing effects of topical Phenytoin with normal saline in 100 patients of leprosy. Pendse et al.(4) studied a total of 75 patients with various types of wounds including burn, post cellulitic, traumatic, amputation stump, postoperative and nonspecific etiology.

Phenytoin Sodium has also been tried in the management of Pressure sores and venous ulcers with minimal side effects.(5)

MATERIALS AND METHODS: This prospective study of assessment of Efficacy of topical Phenytoin Sodium dressing as compared to conventional moist dressing in the management of leg ulcers was carried out in patients admitted to SVRRGG Hospital, Tirupati during the period from January 2014 to August 2015.

One Hundred and Eight cases of Leg Ulcers were taken into study, of which 54 were randomly allocated to the Control group (Treated with moist Saline dressings) and 54 were allocated to the Test group (Treated with topical Phenytoin Sodium dressing). The Randomisation was done by allotting the alternate patients, by their time and date of Admission.

\section{Exclusion Criteria:}

- Malignant and Tuberculous Leg ulcers.

- Patients with proven allergy to Phenytoin.

- Pregnant women.

Application of Dressings: The patients in test group were tested for allergy to phenytoin, with standard intradermal injection of $0.1 \mathrm{ml}$ of phenytoin. A single $2 \mathrm{ml}$ Phenytoin sodium ampule $(50 \mathrm{mg} / \mathrm{ml})$ was broken just prior to dressing and the phenytoin solution was drawn into a sterile 2cc syringe. This $2 \mathrm{ml}$ of phenytoin sodium solution was mixed into a sterile cup containing $18 \mathrm{ml}$ of distilled water, to make it a solution with concentration of $5 \mathrm{mg} / \mathrm{ml}$. Sterile gauze was soaked in the solution for a minute and then placed over the leg ulcer.

Conventional Dressing was done with Normal Saline. At the end of 14 days the wounds in both the groups were inspected and the following parameters noted:

1. Surface Area of the Ulcer, as measured by a sterile gauze being placed over the ulcer and then cut to the shape of the ulcer.

2. Rate of granulation tissue formation - as percentage of the ulcer surface area covered by granulation tissue

3. Graft Take up - Skin graft take up as a percentage of ulcer surface area.

Once the wound was covered by healthy granulation tissue and bacterial growth was controlled by repeated pus cultures and sensitivities and appropriate antibiotics, both the groups were subjected to split thickness skin grafting, by the same surgeon. The grafted ulcers were reassessed at the end of the fifth post-operative day.

The results obtained were statistically evaluated and the main parameters, which were analyzed, were:

- Rate of granulation tissue formation.

- Decrease in the Surface Area of the Ulcer.

- Graft survival and up take. 


\section{ORIGINAL ARTICLE}

Apart from these parameters, for Socio-economic concerns another parameter was studied, that is 'Duration of hospital stay'

\section{RESULTS:}

\begin{tabular}{|c|c|c|}
\hline & CONTROL GROUP & TEST GROUP \\
\hline Number & 54 & 54 \\
\hline Age & $20-60$ & $25-60$ \\
\hline Male: Female & $30: 24$ & $36: 18$ \\
\hline Ulcer Surface Area & $10-80 \mathrm{~cm} 2$ & $30-95 \mathrm{~cm} 2$ \\
\hline
\end{tabular}

Table 1: Distribution of Patient Characteristics

From the Table above, it is clearly demonstrated that the patient characteristics were well matched.

\begin{tabular}{|c|c|c|}
\hline ETIOLOGY & CONTROL GROUP & TEST GROUP \\
\hline Traumatic & 8 & 7 \\
\hline Trophic & 13 & 12 \\
\hline Venous Ulcer & 37 & 5 \\
\hline Diabetes & 18 & 20 \\
\hline Infection & 8 & 10 \\
\hline
\end{tabular}

Table 2: Distribution of Etiology of Leg Ulcers

\begin{tabular}{|c|c|c|}
\hline \% GRANULATION TISSUE & CONTROL GROUP & TEST GROUP \\
\hline$>90$ & 6 & 20 \\
\hline $81-90$ & 6 & 12 \\
\hline $71-80$ & 5 & 6 \\
\hline $61-70$ & 8 & 7 \\
\hline $51-60$ & 22 & 5 \\
\hline $41-50$ & 7 & 4 \\
\hline \multicolumn{2}{|c|}{ Table 3: Distribution Based On Granulation } \\
\hline \multicolumn{2}{|c}{} \\
\hline
\end{tabular}

The efficacy of the dressing was assessed as the percentage of ulcer surface area covered by healthy granulation tissue after 14 days.

The mean rate of granulation tissue formation in control group was $63.96 \%+14.58$ (SD) and in test group it was $81 \%+16.67$ (SD) of total ulcer area.

\begin{tabular}{|c|c|c|}
\hline \% OF GRAFT TAKE UP & CONTROL GROUP & TEST GROUP \\
\hline $81-100$ & 18 & 40 \\
\hline $61-80$ & 24 & 08 \\
\hline$<60$ & 12 & 06 \\
\hline Table 4: Distribution Based On Graft Uptake \\
As Assessed On 5th Post-Operative Day \\
\hline
\end{tabular}




\section{ORIGINAL ARTICLE}

Mean graft uptake of control group was $68.18 \% \pm 11.45$ (SD) and mean graft uptake of test group was $82.57 \% \pm 13.78(\mathrm{SD})$.

A 'p' value of less than 0.05 is obtained, which is significant.

\begin{tabular}{|c|c|c|}
\hline NO. OF DAYS OF HOSPITAL STAY & CONTROL GROUP & TEST GROUP \\
\hline $11-20$ & 0 & 8 \\
\hline $21-30$ & 4 & 32 \\
\hline $31-40$ & 4 & 6 \\
\hline $41-50$ & 24 & 4 \\
\hline $51-60$ & 12 & 2 \\
\hline $61-70$ & 4 & 2 \\
\hline$>70$ & 6 & 0 \\
\hline \multicolumn{2}{|c|}{ Table 5: Distribution Based on Duration of Hospital Stay } \\
\hline
\end{tabular}

The mean hospital stay in control group was 54 days $\pm 10(\mathrm{SD})$ and the mean hospital stay in test group was 31.59 days $\pm 10.9(\mathrm{SD})$.

A ' $p$ ' value of less than 0.05 was obtained, which is significant.

DISCUSSION: In 1939, Kimball first observed that gingival hyperplasia occurred in some patients treated with phenytoin. This stimulated the study regarding the potential use of phenytoin in wound healing.(6) Shapiro carried out the first clinical trial in 1958 and found out that periodontal patients with surgical wounds who were pretreated with oral phenytoin had less inflammation, less pain, and accelerated healing as compared to controls.(7) Subsequently, it was seen that phenytoin promoted the healing of dental extraction sockets and also increased the tensile strength of skin wounds. ${ }^{8,9)}$ There are studies and case reports about the use of topical phenytoin for a wide variety of soft tissue infections and ulcers.

Menezes et al., Bogaert et al., and Bansal and Mukul showed the usefulness of topical phenytoin in lepromatous trophic ulcers. ${ }^{(1)}$ El Zayat examined the effects of topical phenytoin on decubitus ulcers and missile wound injuries and found it to be useful.(10) Phenytoin showed positive results in the treatment of gluteal abscesses secondary to intramuscular injection in a study conducted by Lodha et al.(11) Pendse et al. found antibacterial activity of phenytoin in the wound healing process. ${ }^{(4)}$

Local pain relief due to membrane-stabilizing action of topical phenytoin therapy has been observed in several studies.(12,13) Topical application of phenytoin results in direct access of the drug to the target site and avoids the risk of getting systemic side effects.(13)

Increased rate of granulation tissue formation was seen in test group (Topical Phenytoin) when compared to the control group (Normal Saline). Decrease in the Ulcer surface area was faster and better in the Phenytoin group as compared to the control group. Better Graft take up was seen in the Phenytoin group as compared to the control group. Shorter duration of hospital stay was observed in the Phenytoin group as compared to the Control group.

The present study with Phenytoin solution clearly demonstrates an edge over moist saline dressings, hence Topical Phenytoin solution may be considered as a superior alternative to moist Saline dressing. 


\section{ORIGINAL ARTICLE}

CONCLUSION: In this era of global Economic Comparison, the cost of treatment of chronic leg Ulcers and its financial impacts are very important for the individual and the Society. The cost effectiveness of topical Phenytoin over conventional dressing makes it a better alternative, in the management of leg Ulcers.

\section{LIMITATIONS OF THE STUDY:}

- Complete healing of the ulcer without grafting has not been taken as a parameter because, larger ulcers were taken for study which required split skin grafting to avoid prolonged morbidity of the individual.

- Another important limitation of the present study is its sample size.

- The cost burden on the patient is also not completely analyzed in this study.

\section{REFERENCES:}

1. Bansal NK, Mukul, Comparison of topical Phenytoin with normal saline in the treatment of chronic trophic ulcers in Leprosy. Int J. Dermatol. 1993;

2. Bhatia A, Prakash S, Topical Phenytoin for wound healing, Dermatol Onlie J. 2004 Jul 15:10(1):5.

3. AA Hasamnis, BK Mohanty, Muralikrishna and S. Patil, Evaluation of Wound healing effect of Topical Phenytoin on Excisional wound in Albino Rats, J Young Pharm.2010 Jan-Mar;2(1): 5962.

4. Pendse AK, Sharma A, Sod ani A, Hada S, "Topical Phenytoin in wound healing". Int. J. Dermatol 1993; 32: 214-7.

5. Anstead GM, Hart LM, Sunahara JF, Liter ME, Phenytoin in Wound Healing, Ann Pharmacother. 1996 Jul-Aug: 30(7-8):768-75.

6. Kimball OP, Horan TN. The use of Dilantin in the treatment of epilepsy. Ann Intern Med. 1939; 13:787-93.

7. Shapiro M. Acceleration of gingival wound healing in non-epileptic patients receiving diphenylhydantoin sodium. Exp Med Surg. 1958; 16:41-53.

8. Goebel RW. Sodium diphenylhydantoin association with oral healing. J Oral Surg. 1972; 30:191-5.

9. Shafer WG, Beatty RE, Davis WB. Effect of Dilantin sodium on tensile strength of healing wounds. Proc Soc Exp Biol Med. 1961; 98:348-50.

10. El Zayat SG. Preliminary experience with topical phenytoin in wound healing in a war zone. Mil Med.1989; 28:347-50.

11. Lodha SC, Lohiya ML, Vyas MC, Bhandari S, Goyal RR, Harsh MK. Role of phenytoin in healing large abscess cavities. Br J Surg. 1991; 78:105-8.

12. Rhodes RS, Heyneman CA, Culbertson VL, Wilson SE, Phatak HM. Topical phenytoin treatment of stage II decubitus ulcers in the elderly. Ann Pharmacother. 2001; 35:675-81.

13. Talas G, Brown RA, McGrouther DA. Role of phenytoin in wound healing-a wound pharmacology perspective. Biochem Pharmacol. 1999; 57:1085-94. 


\section{ORIGINAL ARTICLE}

\section{AUTHORS:}

1. Srikanth Reddy Challapalli

2. Munikrishna Salavakam

3. Srihari Rao Bathalapalli

4. Sujana Thalamati

\section{PARTICULARS OF CONTRIBUTORS:}

1. Assistant Professor, Department of Surgery, Sri Venkateswara Medical College, Tirupati.

2. Senior Resident, Department of General Surgery, Sri Venkateswara Medical College, Tirupati.

3. Professor, Department of Surgery, Sri Venkateswara Medical College, Tirupati.

FINANCIAL OR OTHER COMPETING INTERESTS: None
4. Assistant Professor, Department of Gynaecology, Deendayal Medical College, Thiruvallur.

\section{NAME ADDRESS EMAIL ID OF THE} CORRESPONDING AUTHOR:

Dr. Srikanth Reddy Challapalli, Assistant Professor, Department of Surgery, Sri Venkateswara Medical College \& SVRRGGH, Tirupati.

E-mail: csrikanth_ms@yahoo.co.in

Date of Submission: 23/09/2015. Date of Peer Review: 24/09/2015. Date of Acceptance: 05/10/2015. Date of Publishing: 13/10/2015. 